\title{
UIT DE WORDINGSGESCHIEDENIS VAN HET CHARTER VAN 1804.
}

\author{
DOOR
}

Dr. F. W. STAPEL.

Op advies van den Raad der Aziatische Bezittingen benoemde het Staatsbewind bij besluit van 11 November 1802, No. 41 ,eene commissie, om binnen den kortst mogelijken tijd het Staatsbewind te dienen van consideratiën en advijs omtrent den voet en wijze, waarop in het vervolg de handel op 's Lands bezittingen in de Oost-Indiën zourle behoren gedreven, en die bezittingen bestuurd te worden, in diervoegen, dat aan dezelve de hoogst mogelijke trap van welvaart, aan den koophandel dezer Republiek het meeste nut, en aan 's Lands finantiën het meeste voordeel worde aangebracht”.

Den 31en Augustus van het volgende jaar kwam deze commissie gereed met haar Consideratiën en Advijs, die vergezeld waren van een zevental bijlagen, waarvan de eerste, bijlage $\mathrm{A}$, het Charter vormt. Deze stukken zijn alle in extenso afgedrukt bij Mrjer, Verzameling ran Instructiën ${ }^{1}$ ), blz. 117 en volgende, waardoor wij kennis hebben van het resultaat. Op het Rijksarchief bevinden zich in den bundel Staatsbewind No. 442 de notulen en correspondentie van genoemde commissie, en hoewel die notulen vrij summier zijn, en bovendien een aantal bijlagen ontbreken, geven zij toch belangrijke inlichtingen over de wordingsgeschiedenis van het eerste reglement op het bestuur van Indië na den ondergang der Compagnie ${ }^{2}$ ).

Het besluit van 11 November 1802 benoemde tot leden der commissie — in alphabetische volgorde - de burgers

1) Batavia, 1848 .

2) Zie ook Schiff : De Koloniale Politick onder den Raadpensionaris Rutger Ian Schimmelponinck, in Bijdragen Kon. Instituut, 1864, blz. 378-379, Vax Deventer, Bijdragen tot de kennis van het Landelijk Stelsel op Java, I. blz. 5-13, en Grashurs, De Regecrings-Reglementen van Ncd.-Indï, benevens het Charter zan Nederburgh, Le:den, 1893, blz. IX-XI. Het Charter, zonder de Consideraciën cn de andere bijligen, aldaar, blz. 189-216. 
D. van Hogendorp,

Mr. J. Meerman,

Mr. S. C. Nederburgh,

F. O. J. Pontoy,

Mr. W. Six,

A. Verhuell, en

R. Voûte.

Nederburgh en Verhuell schreven aan het Staatsbewind, dat zij de benoeming niet konden aanvaarden, daar zij niet wenschten samen te werken met Van Hogenlorp, op grond van de tegen dezen in Indië uitgebrachte beschuldigingen. Bij de besluiten van 29 November 1802, No. 34a en 34b - gelijkluidend - berichtte het Staatsbewind aan de beide genoemde burgers, dat de fiskaal bij den Raad der Aziatische bezittingen verklaard had: ,dat de bewijzen, welke tot fundament van deze beschuldigingen in zijn handen waren gesteld, naar rechten niet genoegzaam waren om daarop eene wettige actie te kunnen institueeren"; dat dus die beschuldigingen niet mochten beletten den burger Van Hogendorp in eenige Staatscommissie te benoemen; dat het Staatsbewind hem bovendien voor enkele dagen benoemd had ,tot eene aanzienlijke missie van wegens desen Staat buiten 's Lands" - dit sloeg op het toen nog geheime besluit van 26 November 1802, om den gezant te Sint-Petersburg, Willem Buys, terug te roepen en Van Hogendorp derwaarts te zenden -; dat mitsdien het Staatshewind vertrouwde „dat de burger S. C. Nederburgh zich ook niet verder zal laten terughouden om deszelfs benoeming in die commissie aan te nemen, en verder van het caracter van den burger Nederburgh en deszelfs gevoelens omtrent zijn vaderland verwagt, en desnoods vordert, dat hij alle personele redenen, welke hij vermeenen mogt te hebben om gebeurde zaken te ressenteren.... zal ter zijde stellen, en alsnog aan het hem gemanifesteerde verlangen van het Staatsbewind.... zal voldoen".

Beide burgers - Verhuell had een volkomen gelijkluidend schrijven ontvangen -- namen daarop hun benoeming aan.

Primo December 1802 kwamen de benoemden voor het eerst bijeen in het „Hotel van het Staatsbewind” in Den Haag; zij werden daar ontvangen door de Commissie van Marine en Coloniën uit het Staatsbewind, namens hetwelk burger Besier de nieuwe „Commissie tot de Oost-Indische Zaken" verwelkomde en installeerde. Zijn rede werd door Van Hogendorp beantwoord. Nadat de leden van het Staatsbewind vertrokken waren, nam Van Hogendorp voorloopig de leiding 
op zich en stelde voor, allereerst een president te benoemen, als hoedanig met algemeene stemmen Mr. J. Meerman, federalistisch lid van het Wetgevend Lichaam, gekozen werd. Men besloot vervolgens, dagelijks te vergaderen van 10 tot 1 uur, uitgezonderd 's Zondags. Tot amanuensis - secretaris - benoemde de commissie den burger Louis Corneille Mazel.

Uit de notulen blijkt, dat het werk in hoofdzaak is gedaan door Van Hogendorp, Nederburgh en Six ; het aandeel van Verhuell bepaalde zich tot adviseering in zake de defensie, terwijl de andere leden weinig naar voren traden.

Men besloot, allereerst te spreken over den handel, daarna over het bestuur. Uit die volgorde zou dan tevens blijken, in hoeverre de handel moest worden ,geconnecteerd" aan het bestuur. Aan Van Hogendorp, Nederburgh en Voûte werd verzocht, een overzicht te willen opstellen van de wijze, waarop de handel onder de Compagnie was gedreven. $Z \mathrm{ij}$ brachten in de vergadering van 27 December 1802 rapport uit, wat op eigenaardige wijze geschiedde: elk van hen las namelijk een door hem persoonlijk opgestelde „Memorie van éclaircissementen" voor, welke drie memories ${ }^{1}$ ) vervolgens ter lezing werden gelegd. In den loop der besprekingen werd op 3 Januari 1803 aan Nederburgh verzocht, meer in het bizonder zijn meening te willen geven aangaande den handel op Java, en hij leverde reeds den 13den dier maand een memorie dienaangaande in, die werd voorgelezen. Hoewel de notulen er geen melding van maken, komt men tot de conclusie, dat Van Hogendorp het met den inhoud dier memorie niet eens was: hem werd althans verzocht, de vergadering te willen dienen van zijn consideratiën dienaangaande, wat hij nakwam door in de vergadering van 17 Januari 1803 eveneens een memorie over te leggen. Bij de debatten dienden Meerman, Six, Pontoy, Verhuell en Voûte schriftelijk hun adviezen in, terwijl Nederburgh en Van Hogendorp hun memories mondeling toelichtten. Den 24en Januari werd ,prealabel besloten, dat als gronden van die verbeteringen, waarvoor het inwendig bestuur van het eiland Java vatbaar kan worden geoordeeld, niet behoren in consideratie te komen de beginselen van eigendom van grond onder de gemeene Javanen, en de afschaffing van alle de Heerendiensten", voor welke beginselen, naar bekend is, Van Hogendorp warm voelde. Uit de notulen blijkt evenwel

1) Het is te betreuren, dat deze memories, even als de talrijke andere, die beneden genoemd zullen worden, en waaronder zeer belangrijke waren, niet konden worden teruggevonden. 
nergens, dat nu voor hem alle aardigheid er af was; hij woonde ook verder de vergaderingen geregeld bij, en legde 7 Februari 1803 een memorie over aangaande de defensie, zulks naar aanleiding van een advies over hetzelfde onderwerp, reeds 5 Januari door Verhuell ingediend: Een derde verhandeling over de defensie volgde den 15den Februari van de hand van Pontoy.

Van veel belang is een andere memorie van Mrs. Six en Nederburgh, eveneens den 15den Februari 1803 ingediend, betreffende de inrichting der rechtbanken en de administratie der justitie ${ }^{1}$ ). Ze werd aan de leden rondgezonden, en toen den 3den Maart de besprekingen er over zouden beginnen, reikte Van Hogendorp alweder een memorie over, ,houdende desselfs consideratiën over dit onderwerp". Besloten werd, ook deze rond te zenden, om ,op den inhoud dier beide memoriën nader en gelijktijdig te worden gedelibereerd". De notulen van 10 Maart 1803 en volgende dagen deelen telkens slechts mede, dat nader over de justitie is gedelibereerd, zonder verdere bizonderheden. Op verzoek der vergadering leverden Six en Nederburgh den 16en April de eindredactie in, die met dankzegging aan de beide genoemden werd goedgekeurd. Wij vernemen niets van de wenschen en argumenten van Van Hogendorp; succes heeft hij niet gehad, daar het ontwerp-Six-Nederburgh vrijwel onveranderd is overgenomen in de artikelen 58 tot 89 van het Charter.

Dien zelfden 16den April 1803 diende Nederburgh de door hem opgestelde redactie in der artikelen, die betrekking hadden op het bestuur en de ambtenaren. Het Staatsbewind had er op aangedrongen alvast de resultaten over dit onderdeel te mogen vernemen, daar een nieuwe Gouverneur-Generaal moest worden benoemd ${ }^{2}$ ).

Reeds twee dagen te voren, 14 April 1803, had de Commissie voor Marine en Coloniën onder zeer vleiende bewoordingen Dirk van Hogendorp bij het Staatsbewind aanbevolen voor het GouverneurGeneraalsambt. Het Staatsbewind verzocht zijn leden, er hunne gedachten over te laten gaan, om dan den 21sten over de benoeming te beslissen. Dit is evenwel niet geschied, zonder dat de redenen genoemd worden; eerst 24 Mei 1804 verzocht het Staatsbewind aan

1) Ook deze memorie is niet meer te vinden; de Consideratiën zeggen echter : ,waarvan de hoofdzakelijke inhoud voorkomt bij het Charter, van art. 58 tot art. 89". Zie Mijer, blz. 202.

2) Mr. Pieter Gerardus van Overstraten was 22 Augustus 1801 overleden, en opgevolgd door den ruim 60-jarigen Joannes Siberg, die reeds in Januari 1802 zijn ontslagaanvrage teekende. 
den Raad der Aziatische Bezittingen opgave van geschikte personen voor het ambt van Gouverneur-Generaal.

Intusschen had Van Hogendorp den 18den April 1803 aan de vergadering medegedeeld, dat hij, ,,zijnde benoemd tot extraordinairen envoié en minister-plénipotentiary dezer Republiek bij het Hof van St. Petersburg', de verdere vergaderingen niet meer zou kunnen bijwonen, ,met bijvoeging echter, dat bereid was haar Generaal Rapport met zijne onderteekening te helpen bekrachtigen, waartoe dan ook door denzelven die onderteekening bij voorraad onder den amanuensis dezer Commissie was gedeponeerd, en met verdere toewensching van den besten uitslag harer ten einde loopende werkzaamheden”. Waarop hij door den president namens de commissie ,met wederkerigen heilwensch en met dankzegging voor desselfs gepresteerde medewerking is gevalediceerd".

In de vergaderingen van 6 tot 18 Mei 1803 werden de eindredacties der stukken goedgekeurd. Nederburgh was de opsteller geweest van het Charter (bijlage $\Lambda$ ), van de Instructie voor het Hoge Gerechtshof van Bataafsch Indiën (D) ${ }^{1}$ ), en van het Reglement omtrent de judicature over de Buiten en Prijzen (D 1). Daarentegen waren de Instructie voor den Raad der Aziatische Bezittingen (B), de Instructie voor den Gouverneur-Generaal (C), en het Octrooi voor de Compagnie tot het inkoopen van thee in China (E) door Six opgesteld. Thans bleef nog over de redactie der Consideratiën zelf, waarvan bovengenoemde stukken de bijlagen vormden. Ook dit omvangrijke Generaal Rapport, zooals de Consideratiën wel genoemd werden, is geredigeerd door Nederburgh; het werd den 31en Augustus 1803 goedgekeurd. Tevens hechtte de vergadering dien dag haar approbatie aan nog een bijlage (D 2), mede door Nederburgh opgesteld: , Instructie voor de advocaten-adviseurs bij de Schepenbank te Batavia en de subalterne rechtbanken op de Buitenkantoren" ${ }^{2}$ ). Ten slotte

1) De oprichting van een Hoog Gerechtshof (MuJER, o.l. blz. 201 e.v.; 244 e.v.; 289 e.v.) werd opnieuw bepaald in het Reglement van 1806 (zie Gr.ıshuss, o.1. blz. 226 e.v.). De Instructie van Daendels, van 1807 , spreekt van ,het Gerechtshof van Justitie te Batavia”; het R. R. van 1815 van ,het Hoog Gerechtshof". Dit lichaam kwam evenwel eerst in het begin van 1819 tot stand; de oprichting was een der laatste daden van de scheidende CommissarissenGeneraal. Zie ook het door hen in 1818 uitgevaardigde R. R. bij Mrjer, blz. 412 e.v.

2) Zie voor dit merkwaardig instituut MrJer, blz. 212. Opgemerkt worde, dat aldaar, en in art. 84 van het Charter (blz. 252) ook Samarang wordt genoemd als plaats, waar een advocaat-adviseur aan de rechtbank zou worden toegevoegd. In de voor de advocaten-adviseurs opgestelde Instructie komt de naam Samarang evenwel niet voor. (Zie ook Mrjer, blz. 323).

D1. 90. 
kwam men overeen, dat de geheele commissie de resultaten van haar arbeid den 1sten September 1803 persoonlijk aan het Staatsbewind zou gaan overhandigen.

Behalve de hiervóór besproken stukken bood de commissie ook nog een geheim schrijven aan, mede van 31 Augustus 1803, dat Mijer niet heeft gekend. $\mathrm{W}$ ij laten dit document hier volgen, met weglating slechts van dat gedeelte, hetwelk de salarieering der ambtenaren bespreekt, en waarvan het niet duidelijk is, waarom dat geheim moest blijven. Mogelijk vond men het minder gewenscht publiek te maken, dat sommige ,burgers” salarissen zouden genieten van 20.000, 15.000, 12.000 etc. rijksdaalders. Speciaal het oordeel, in dit geheime schrijven uitgesproken over de toen zittende leden van den Hoogen Raad van Justitie te Batavia, verdient de aandacht ${ }^{1}$ ).

Secreet.

In Den Haag, den 31 Augustus 1803.

De Commissie tot de Oost-Indische Zaken aan

Het Staatsbewind der Bataafsche Republiek.

\section{Burgers!}

Daar wy het mogelijk achten, dat de consideratiën en advis omtrent den aanstaanden voet van het Bestuur der Aziatische Bezittingen der Bataafsche Republiek, en den handel op dezelven, welke wy de eer hadden, ter voldoening aan Ulieder besluit van den 11e November des voorleden jaars, No. 41, by onze besloten missive van heeden Ulieden aan te bieden, publiciteit zullen verkrygen, en wy het in dat geval van belang achten te zijn, dat dit stuk en de bylagen, daartoe gehorende, in hun geheel kunnen blyven, en zodanig aan hen, welken dezelve onder het oog zullen krygen, worden voorgelegd, hebben wy, onder Ulieder gunstige welduiding, begreepen, afzonderlijk by deeze secreete missive te moeten verhandelen eenige zaaken, welke uit derzelver aart, of om Staatkundige redenen, ons minder geschikt zijn voorgekomen om, immers vooralsnog, ter kennisse van het publiek te komen, terwijl wy, volgens de ordre daaromtrent by onze voormelde consideratiën in acht genomen, eerst zullen spreeken van die, welke den handel, en vervolgens van die, welke het Bestuur der Indische Bezittingen betreffen.

1) Sedert 1798 voerde de Raad van Justitie te Batavia het praedicaat Hooge, om te kennen te geven, dat deze Raad feitelijk een hoogeren rang innam dan de overige Raden van Justitie. Voor de samenstelling zie beneden. 
Tot de eersten behoort het subsisteerend contract met den koning van Trevankoor, volgens welk deeze vorst verplicht is de peeper, in zyne Staaten vallende, uitsluitend aan de O. I. Compagnie, of aan den Staat, nu deeze getreeden is in de rechten derzelve Compagnie, te leveren $\left.{ }^{1}\right)$. Dit, anderzints zeer voordeelig contract, heeft deszelfs kragt en uitwerking verlooren, naar mate het vermogen der Engelschen om de West van Indiën is aangegroeid, en het de Nederlandsche O. I. Compagnie aan macht ontbrooken heeft, om zich in dien oort genoegzaam te doen respecteeren.

Het is waarschynelijk, dat deeze gesteldheid van zaaken, en de geneigdheid van dien vorst daaromtrend thans gunstiger zullen zijn, dan vóór den jongsten oorlog; in zodanig geval zoude het ernstige overweging kunnen verdienen, hem by zodanige overeenkomst, als tot het meeste voordeel van den Staat zoude te treffen zijn, van die verplichting te ontslaan, en den vryen invoer van peeper te Cochim, mitsgaders den handel in clat artikel, alleen onder heffing van een bepaald uitgaand recht, open te stellen, waardoor waarschynelijk het grootste gedeelte der aanzienelyke hoeveelheid peeper, in het rijk van Trevankoor en verder op de Mallabaarsche kust wassende, welke thans geheel komt in handen der Engelschen, naar Cochim zoude werden afgevoerd, en zeer veel tuebrengen om die plaats, welke buitendien tot den handel zeer gelegen is, te doen bloeien, en het aandeel der Bataafsche Natie in den peeperhandel te vergrooten.

Wy veroorloven ons dierhalven, zulks aan Ulieder overweging te submitteeren, schoon in allen gevalle naauwkeurige berichten omtrend den staat, waarin die Bezitting, ingevolge het vredestractaat van Amiens, zal zijn teruggegeven, en den verderen toestand der zaaken aldaar, zullen moeten worden afgewacht, alvorens daaromtrend iets met vrucht te kunnen besluiten.

Eene andere zaak, den handel betreffende, waarop wy verplicht z.ijn Ulieder attentie te vestigen, is de tegenwoordige toestand van den handel in amphioen en salpeter in Bengalen. Het is bekend, dat dezelve vry is voor de Nederlandsche O. I. Compagnie, indien men

1) Dit is niet geheel juist. Den 15den Augustus 1753 had de Compagnie een verdrag van vrede en vriendschap gesloten met den koning van Trevancore, aan de kust van Malabar. Bij artikel 4 beloofde die vorst, alle producten uit zijn land alleen aan de Nederlandsche Compagnie te leveren, met uitzondering slechts van 1000 lasten peper per jaar, die hij volgens een bestaand contract aan de Engelsche Compagnie moest afstaan. Voor de Nederlanders bleven dan, naar raming, nog 5000 lasten jaarlijks over. 
haare wettiglijk verkreegen rechten in aanschouw neemt, doch dat ook deeze rechten hebben moeten zwichten voor de willekeur der Engelschen, die zich den uitsluitenden handel van die beide artikelen hebben aangematigd, zonder dat het aan eenige andere Natie, en ook niet aan de onze, mogelijk is geweest, zich daartegen te verzetten; de O. I. Compagnie heeft zich eindelijk moeten vergenoegen met zodanige hoeveelheden amphioen en salpeter, als het de Engelschen goeddacht haar jaarlijksch toe te bedeelen; in het jaar 1788 zijn er wel in deeze residentieplaats ${ }^{1}$ ) met den Engelschen minister onderhandelingen geëntameerd geweest, waartoe het laatste vredestractaat destijds aanleiding gaf, om daaromtrent meer billyke schikkingen te maken, doch dezelve heblen niet tot stand kunnen worden gebragt ${ }^{2}$ ); in dit ogenblik is daarop althans geen het minste uitzicht; echter diend deeze zaak, na ons inzien, niet uit het oog te worden verlooren, wanneer de gelegenheid zich weder mogt opdoen, hetzy om de rechten, welke daaromtrent thans aan den Staat zijn overgegaan, te doen herleeven, hetzy om alsnoch vaste schikkingen te maken om aan den Staat jaarlijks zekere hoeveelheid amphioen en salpeter tot billyke pryzen te verzeekeren, indien zy zulks van haar belang oordeelt te zijn, hetwelk vooral ontrent de salpeter misschien de oplettendheid van het Gouvernement verdient.

Wat verder het toekomstig Bestuur in Oost-Indiën aangaat, aan welkers deugdzaame zamenstelling wy een zo byzonder gewicht hechten, moeten wy, behalven hetgeen daaromtrend by onze meermelde consideratiën voorkomt, nog doen opmerken de noodzakelijkheid, zo wel om brave en kundige lieden, zich daar te lande bevindende, voor den dienst van den Staat te conserveeren, ten einde van hunne plaatselyke kennis, die in veele opzichten onontbeerlijk zal bevonden worden, en verdere bekwaamheden, een nuttig gebruik te kunnen maken, als om het nieuw Bestuur ook, wat de administratie

1) 's-Gravenhage.

2) Prins Willem V had bij schrijven van 18 November 1787 in zijn hoedanigheid van Opperbewindhebber aan de Zeventien voorgesteld, een commissie te benoemen, die een onderzoek zou instellen naar den staat van de Compagnie, en voorstellen zou indienen tot verbetering daarvan. In hun vergaderig van 13 December daaraanvolgende benoemden Heeren-XVII tot leden dier commissie de bewindhebbers Van der Oudermeulen, Pous, Graafland en Van Teylingen, en den advocaat der Compagnie Nederburgh. Zij trachtten o.m. door besprekingen met den Engelschen gezant voor de Compagnie een grooter aandeel te krijgen in den handel op Bengalen, wat niet gelukte. Men vindt het rapport dezer commissie, dat door Nederburgh was opgesteld, in het resolutieboek van Heeren-XVII, op 28 en 29 Maart 1788. 
der Politie aangaat, gedeeltelijk, en die der Justitie in het hoogste ressort geheel, te doen bestaan uit mannen, van hier uitgezonden, en zo volkomen bereekend en geschikt tot de bedieningen, waartoe zy zullen worden aangesteld, als door ons by de voormelde consideratiën met die vrymoedigheid, welke het gewicht der zaak en het belang van het vaderland ons tot een plicht maakten, is voorgesteld.

Tot dien einde zouden wy dierhalven van advies zijn, dat, wanneer door het Staatsbewind zal worden voorzien in de nog vaceerende post van Gouverneur-Generaal, op den door ons voorgeslagen voet het thans fungeerende lighaam der Hooge Regeering tevens op eene honorabele wyze zoude behooren te worden ontslagen, en opnieuw door het Staatsbewind aangesteld de drie ordinaire en twee extraordinaire Raden, welke, benevens den Gouverneur-Generaal, het nieuw Opperbestuur zullen uitmaken, en wel één ordinaris en één extra-ordinaris Raad om van hier na derwaarts te worden gezonden, en de overigen uit de bekwaamste en op het gunstigst bekende eerste ambtenaren uit Indiën, alsmede dat van de agt leeden, welke met den vice-praesident onder het praesidie van een der ordinaris Raden zullen uitmaken het nieuw op te richten Collegie van Financiën en Domeinen, drie van hier zouden behooren te worden uitgezonden.

Doch wat aangaat het Hoge Gerechtshof van Indiën, moeten wy met weerzin betuigen, dat ons geen enkele reeden is voorgekomen, welke het wenschelijk, veel min noodzakelijk zoude kunnen doen achten, om eenige der tegenwoordige leeden of ministers van den Hogen Raad van Justitie, te Batavia resideerende, by hetzelve te employeeren ${ }^{1}$ ): de diepe onkunde en ingewortelde afkeer van dit collegie voor alle superieure magt in Indiën, de menigvuldige en ergerlijke botzingen, waartoe zulks nu zedert verscheiden jaren tot nadeel zowel van de publieke authoriteit als van het aanzien en respect der Justitie, heeft aanleidling gegeven, zodat dit laatste als geheel verlooren is, doen ons alle verbetering der administratie van de Justitie als vruchtelcos beschouwen, indien niet kan worden voorgekomen, dat die ongelukkige geest van onkunde en van dwaaze heerschzugt en waanwijsheid, door welke de voormelde Raad het publiek vertrouwen

1) In 1803 bestond de Hoge Raad van Justitie uit de volgende personen: president Mr. Jacob George van Rossum; leden Mr. Albert Cornelis Hartman, Mr. Willem Popkens, Andreas Cantbeen, Nicolaas Maas, Mr. Joan Adriaan Doornik, Mr. Frans van Stipriaan, Mr. Willem Jacob van Nes, Mr. Pieter Simon Maurisse, Mr. Bartholomeus Jacobus van Meurs; geassumeerde leden Mr. Jan Reinier Tile, Jan Jacob Vogelaar, David van Lennep. 
onherstelbaar van zich verwyderd heeft, zich aan het nieuwe Gerechtshof mededeele; en hiertoe moet hetzelve niet alleen bestaan uit geheel nieuwe leden en ministers, maar zelfs ware het te wenschen, dat deezen zo weinig gemeenschap mogelijk hadden met de leden van het vorige, ten einde geen gevaar te lopen van besmet te worden door wanbegrippen en vooroordeelen, welke voor de noodzakelyke harmonie en eensgezindheid onder alle classen van ingeseetenen, en voor den dienst der Justitie opnieuw de schadelijkste gevolgen zouden kunnen hebben; kunnende overigens de leden en ministers van den tegenwoordigen Hoogen Raad op eene honorable wyze worden ontslagen met behoud van eenen convenabelen rang en van hunne tractementen tot het einde van hunnen verbonden tijd, indien het Staats Bewind oordeelt, dat de billijkheid dit laatste zoude vorderen $\ldots . .{ }^{1}$ ).

Daar het wyders in bedenking zoude kunnen komen, of niet van de oprichting der door ons voorgeslagene Aziatische en tot den Theehandel geoctroyeerde Compagnie gebruik zoude kunnen worden gemaakt als een middel van schadeloosstelling voor de deelhebbers in de bevorens geoctroyeerde Oost-Indische Maatschappy, vinden wy ons verplicht, daaromtrend tot Ulieder kennisse te brengen, dat zulks wel by ons in overweging is gekomen, te meer daar de aandacht van het publiek reeds met een dergelijk ontwerp was bezig gehouden, doch dat wy zulks als onuitvoerlijk hebben moeten beschouwen, omdat, hetzy men die deelhebbers exclusief tot den theehandel zoude willen octroyeeren, hetzy men hun voor het montant hunner aandeelen het deelgenootschap zoude willen geeven in de voorschreeve nieuw op te richten Compagnie, volgens informatiën van deskundigen geene waarschijnlijkheid zoude overblyven, om het aanzienelijk capitaal, dat nodig zal zijn om dien handel opnieuw, volgens den eisch der belangen van den Staat, weder op te vatten, by elkanderen te krygen. Daar echter de voornoemde deelhebberen eene door het Bataafsche volk erkende aanspraak hebben op schadeloosstelling, en het Staats Bewind niet anders kan verlangen, dan in deeze moeielyke taak de algemeene belangen altijd te blyven beschouwen als onafscheidelijk van de rechten van byzondere lighaamen of ingezeetenen, ware het misschien wenschelijk, dat dezelve konde worden ten einde gebracht; en hoezeer wy anderzints geheel afkeerig zijn van ons in het minste in te laten in eene zaak, welke geen directe betrekking hoe-

1) Hier volgen dan een reeks opgaven van salarissen, pensioenen en emolumenten der diverse besturende en rechtsprekende ambtenaren. 
genaamd heeft tot onze Commissie, mogen wy echter, onder Ulieder gunstige welduiding, niet nalaten op te merken, dat het noodwendig tot de vastigheid van het nieuwe gebouw, hetwelk, indien onze arbeid Ulieder goedkeuring mag wegdragen, het vorige zal moeten vervangen, veel zoude toebrengen, wanneer aan de onaangename discussiën over deeze materie, welke reeds maar al te veel gerugts hebben gemaakt, door zodanige maatregelen, als Gylieden in derzelver wijsheid billijk en geschikt zult oordeelen, alle verdere gelegenheid wierd benomen.

Wy bevelen $\mathrm{U} 1$. in Godes heilige Bescherming, en noemen ons respectievelijk,

De Commissie tot de Oost-Indische Zaken :

J. Meerman

Wm. Six

J. F. Pontor ${ }^{1}$ )

C. A. Verhuell

D. VAN HOGENDORP

S. C. Nederburg

Robert Voûte.

Uit naam van voorz. Commissie

MAZEL.

Wat nu de door Mijer gepubliceerde stukken betreft, dient er in het bizonder de aandacht op te worden gevestigd, dat het Charter, zooals hij dat afdrukt, de redactie geeft, welke de Commissie tot de Oost-Indische Zaken aan het Staatsbewind aanbood. Dit college heef : claarover echter nog het advies gevraagd der Commissie van Marine en Coloniën uit zijn midden, en deze heeft enkele wijzigingen voorgesteld. Bij besluit van 27 September 1804, No. 19a, stelde het Staatsbewind ten slotte cen Charter vast, dat hier en daar nog al afwijkt van het dour Mijer afgedrukte ontwerp der commissie. Dit laatste telde 117 artikelen; het definitieve Charter slechts 108. Daar ook Grashuis het 117 artikelen tellende ontwerp geeft ${ }^{2}$ ), laten wij hieronder naast elkaar volgen de verschillen tusschen het ontwerp van 31 Augustus 1803 en de eindredactie van 27 September 1804.

1) Het benoemingsbesluit geeft de voorletters F. O. J. en spelt den geslachtsnaam Pontoy.

2) Blz. 189-216. 


\section{Ontwerp der Commissie, ingediend 31 Augustus 1803.}

Art. 2 (laatste alinea).

...., mits aan den inhoud van

dit Charter niet contrarieerende

\section{Art. 8.}

Alle vacatures, welke zullen voorvallen in de bediening van Gouverneur-Generaal, zullen vervuld worden door het Staatsbewind der Bataafsche Republiek, uit eene nominatie van drie personen, geformeerd door den Raad der Aziatische Bezittingen, binnen drie maanden, nadat dezelve ter kennisse van het Staatsbewind zullen zijn gekomen.

Art. 12.

Geene militaire Hoofd-officieren kunnen zijn Ordinaire of Extraordinaire Raden, zoo lange zij hunne militaire qualiteit bekleeden.

Art. 13 (aan het slot).

.... ten einde daaruit door het Staatsbewind èèn te worden verkozen, tot finale suppletie der plaats hebbende vacature; des zal de geassumeerde Raad Extra-

\section{Charter voor de Aziatische Bezittingen van de Bataafsche Republiek, vastgesteld 27 September 1804.}

\author{
Art. 2 (laatste alinea).
}

...., mids aan den inhoud vall dit Charter of aan de byzondere bevelen van het Staatsbewind niet contrarieerende....

Art. 8.

Alle vacatures, welke zullen voorvallen in de bediening van Gouverneur-Generaal, worden door het Staatsbewind der Bataafsche Republiek vervuld. De Raad der Aziatische Bezittingen is gehouden, van zodane vacatures kennis te geven aan het Staatsbewind, een maand nadat de tijding zal zijn ingekomen, en alsdan tevens eenige geschikte persoonen tot die bediening aan hetzelve voordragen.

\section{Art. 12.}

Geene militaire officieren kunnen zijn Ordinaire of Extraordinaire Raaden, zoo lange zij hunne militaire qualiteit bekleeden, noch als zodanige in den Raad kunnen worden geassumeerd.

Art. 13 (aan het slot). ..... ten einde daaruit door het Staatsbewind èèn te worden verkozen tot finale suppletie der plaats hebbende vacature; zullende egter het Staatsbewind de 
ordinair het tractement, daartoe staande, genieten $\ldots{ }^{1}$ ).

$$
\text { Art. } 20 .
$$

.... totdat het goedvinden van den Raad der Asiatische Bezittingen zal zijn verstaan....

\section{Art. 34 (slot).}

... doch zal hij deswegens alleen verantwoordelijk zijn.

Art. 36 (slot 1e alinea).

.... zijn gehouden deszelfs ordres te respecteeren en gehoorsamen. nominatie kunnen terugzenden ๔n eene nieuwe vorderen. De geassumeerde Raad Extra-ordinair zal het tractement, daartoe staande, genieten ....

Art. 20.

.... totdat het goedvinden van het Staatsbewind, naar ingenomen consideratiën van den Raad der Asiatische Bezittingen, zal zijn verstaan....

$$
\text { Art. } 34 \text { (slot). }
$$

.... doch, ten einde alle willekeur voor te komen, zal hij deswegens alleen verantwoordelijk zijn.

Art. 36 (slot 1e alinea).

..... zijn gehouden deszelfs ordres te respecteren en te gehoorzamen, voor zoverre dezelve niet strijden met de beveelen, door ofte vanwege het Staatsbewind rechtstreeks aan deselve gegeven, tenware nochtans hij, Gouverneur-Generaal, uit den aart en plaats hebbende omstandigheden zoude kunnen veronderstellen, dat het Staatsbewind, daarvan kundig, anders zoude hebben gedisponeerd; blijvende hij, Gouverneur-Generaal, voor zijne orders alsdan personeel verantwoordelijk, en de officieren verplicht, hem te gehoorzamen.

Art. 36 (slot). Art. 36 (slot).

1) In dit artikel staat bij MrJer een drukfout. Voor: eene nominatie van dic personen leze men.... dric personen. 


$$
\text { Art. } 37 \text { (slot). }
$$

.... bestaan uit eenen vicepresident en agt Raden.

$$
\text { Art. } 39 \text { (slot). }
$$

.... door den GouverneurGeneraal in Rade, nu of in der tijd, zullen worden beraamd en vastgesteld.

\section{Art. 40.} dat alle....

$\ldots$ op het eiland Java; en

$$
\text { Art. } 42 \text { (slot). }
$$

.... alle geldafpersingen of concussiën ${ }^{1}$ ) van den Inlander...

Art. 43.

.... directelijk of indirectelijk, consumabele waaren van geringe waarde alleen uitgezonderd,....

Art. 44 (slot).

....; geen ambtenaar zal tot een ambt van eene hogere classe kunnen worden aangesteld, tenzij hij drie achtereenvolgende jaren gefungeerd hebbe in die classe, waaruit de vervulling geschieden moet.

1) MiJer heeft hier: concessiën.
Art. 37 (slot).

..... bestaande uit een vicepraesident en zes Raaden.

Art. 39 (slot).

..... door den GouverneurGeneraal in Raade, nu of in der tijd, zullen worden beraamd, en door den Raad der Asiatische Bezittingen goedgekeurd en vastgesteld.

Art. 40.

... op het eiland Java; en zorgen dat alle....

Art. 42 (slot).

..... alle geldafpersingen of vexatiën van den Inlander.....

Art. 43.

.... directelijk of indirectelijk, noch te dulden, dat dit door zijne huisvrouwe, kinderen, huisbedienden, of iemand van zijnentwege geschiede, consumabele waaren van geringe waarde alleen uitgezonderd.

Art. 44 (slot).

....; geen ambtenaar zal tot een ambt van eene hoogere classe kunnen worden aangesteld, tenzij hij twee achtereenvolgende jaren gefungeerd hebbe in die classe, waaruit de vervulling geschieden moet; blijvende het egter aan het Staatsbewind onverlet, om in byzondere gevallen, en om gewichtige redenen persoonen, van 
Art. 45 (aanvang).

Alle vacatures van ambten, tot eenige der voormelde vier classen behoorende, worden vervuld door den Gouverneur-Generaal in Rade, op de daartoe staande tractementen en emolumenten; de ambten der vierde classe definitivelijk, doch die der eerste, tweede en derde classen onder approbatie van den Raad der Asiatische Bezittingen. herwaards naar Batavia wordende uitgezonden, of derwaards vertrekkende, te verleenen de bevoegdheid, om dadelijk bij hunne aankomst tot een of ander ambt der derde classe te kunnen worden bevorderd.

Art. 45.

Alle vacatures van ambten, tot eenige der voormelde vier classen behoorende, worden vervuld op de daartoe staande trac. tementen en emolumenten; die der vierde classe door den Gouverneur-Generaal in Raade definitievelijk, die der derde door den Gouverneur-Generaal en Raaden op approbatie van den Raad der Asiatische Bezittingen; die der tweede door den Raad der Asiatische Bezittingen uit eene gemotiveerde voordragt van den Gouverneur-Generaal in Raade; en die der eerste door het Staatsbewind, na ingenomen consideratiën van den Raad der Asiatische Bezittingen.
Art. 45 (slotalinea) wordt
Art. 46.

...; geen ambtenaar vermag.

Art. 46

wordt

Geen ambtenaar vermag....

Zoo rasch....

Zoodra....

Art. 47.

Art. 47 (slot) wordt

Art. 48 (slot).

...; deze moeten drie jaren ....; deese moeten twee jaren, als zodanig in Indiën hebben dienst gedaan, alvorens....

Art. 50. de reis daaronder begrepen, als zodanig in Indiën hebben dienst gedaan, alvorens....

Vervalt. 
Art. 52.

... na verloop van vijf jaren $\ldots$

.... dan alleen wegens de misdaden van Hoog Verraad, en ontvreemding van 's Lands penningen.

Art. 56.

De meest geschikte middelen zullen, met overleg van de Inlandsche regenten, worden beraamd en in het werk gesteld, om in het gebied van de Bataafsche Republiek in Oost-Indiën het lot van den gemeenen Inlander te verbeteren en te verzekeren, alle onregelmatige en willekeurige belastingen af te schaffen, en den landbouw zooveel mogelijk aan te moedigen en uit te breiden; de Inlandsche wetten, zeden en gewoonten zullen bewaard blijven; als gronden van de verbeteringen, waarvoor het inwendig bestuur van het eiland Java vatbaar kan worden geoor(leeld ${ }^{1}$ ), kunnen niet in aanmerking komen de beginselen van eigendom van grond onder de gemeene Javanen, en de afschaffing van alle Heerendiensten.

\section{Art. 57.}

..... mitsgaders benoodigde weidens voor hoorn- en ander vee....
Art. 52 .

.... na verloop van zeven jaaren.....

Vervalt.
Art. 56.

Hoezeer de beginselen van eigendom van grond onder de gemeene Javanen, en de afschaffing van alle Heerendiensten voor het tegenwoordige niet kunnen gelegd worden tot gronden van het inwendig bestuur van het eiland Java, zullen egter de meest geschikte middelen, met overleg van de Inlandsche regenten $^{2}$ ), worden beraamd, om in het gebied van de Bataafsche Republiek in Oost-Indiën het lot van den gemeenen Inlander te verbeteren en te verzekeren, alle onregelmatige en willekeurige belastingen af te schaffen, en den landbouw zooveel mogelijk aan te moedigen en uit te breiden.

1) Het ontwerp heeft hier de verschrijving: geoorloofd, wat zoowel MiJer als Grashuis hebben overgenomen. Dat het moet zijn: geoordeeld, blijkt uit de notulen. Zie ook hierboven, blz. 427.

2) Er staat: Inlandsche regeering, wat evident cen verschrijving is. 
...., doch zal het de pligt van het Indische bestuur zijn, hieromtrent te waken en de noodige voorzorgen te gebruiken, dat de veeteelt in de Bataviasche Bovenlanden door de land-eigenaren niet worde voortgezet of uitgebreid tot nadeel of kwelling van den gemeenen Inlander, of tot praejudicie van de aankweeking van nuttige Land-producten.

\section{Art. 58.}

Er zal een nieuw Hoog Gerechtshof....

.... uit nominatiën van drie persoonen, geformeerd door het Nationaal Gerechtshof;

Art. 59.

... mits in dit geval....

Art. 71.

De Gouverneur-Generaal in Rade, daartoe vanwegens den aangeklaagden zijnde geadieerd, zal vermogen, om goede en gewigtige redenen, te verleenen surcheance van crimineele procedures, bij het Hof aanhangig zijnde, en toch verpligt zijn alvorens daarop te nemen het be1 icht en de consideratiën van het Iof; alleenlijk in gevallen van ciringende roodzakelijkheid en wanneer zonder dat de zaak gevaar zoude kunnen loopen van febragt te worden uit haar geheel, zal de Gouverneur-Generaal in Rade bevoegd zijn te verleenen provisioneele surcheance van procedures, totdat de gere-

Vervalt.

Art. 58.

Er zal een Hoog Gerechtshof ....

Vervalt.

Art. 59.

.... mits in dit laatste geval ....

Art. 71.

De Gouverneur-Generaal in Raade, daartoe vanwegens den aangeklaagden zijnde geadieerd, zal, na ingenomen bericht en consideratiën van het Hof, vermogen te verleenen surcheance van crimineele procedures, bij het Hof aanhangig zijnde. In gevallen van dringende noodzakelijkheid, en wanneer door 't voordgaan der procedures de zaak gevaar zoude kunnen loopen van gebragt te worden uit haar geheel, zal de GouverneurGeneraal in Raade bevoegd zijn te verleenen provisioneele surcheance van procedures; edoch geene finale surcheance kunnen verleenen, dan na te hebben ge- 
quireerde consideratiën en bericht van het Gerechtshof zullen zijn ingekomen.

Art. 75.

Alle de handelingen van het Hoge Gerechtshof zullen onderworpen zijn aan het onderzoek van het Nationaal Gerechtshof, hetwelk, bevindende dat in een of ander opzicht niet naar behooren is geprocedeert.....

.... vereischt wordt, deswegens aan het Staatsbewind zoodanige voordragt doet als hetzelve....

Art. 76.

...., hij wordt verkozen door het Staatsbewind, uit eene nominatie van drie personen, geformeerd door het Nationaal Gerechtshof; in cas van....

Art. 77.

Zij zullen voor het eerst worden aangesteld door het Staatsbewind, uit nominatiën van drie personen, geformeerd door het Nationaal Gerechtshof. In cas van....

Alle vacatures der bediening van tweeden griffier worden door het Staatsbewind vervuld uit nominatiën als voren, ad interim gesuppleerd.... requireerd en ontfangen de consideratiën en bericht van het Gerechtshof.

Art. 75.

Indien aan het Nationaal Gerechtshof eenige klagten over de handelingen van het Hooge Gerechtshof in Indiën worden gedaan, zal hetselve daarna, daartoe grond vindende, onderzoek doen, en daarover het bericht van het Hooge Indische Gerechtshof vragen, en bevindende dat in een of ander opzicht niet naar behoren is geprocedeerd...

.... vereischt wordt, zal het Nationaal Gerechtshof deswegens aan het Staatsbewind zodanige voordragt doen, als hetzelve....

$$
\text { Art. } 76 .
$$

....; hij wordt verkozen door het Staatsbewind. In cas van....

Art. 77.

Zij zuillen voor het eerst worcien aangesteld door het Staatsbewind. In cas van....

.... Alle vacatures der bediening van tweede griffier worden door het Staatsbewind vervuld en ad interim gesuppleerd.... 
Art. 84 .

..... door eenen advocaatadviseur, welke niet jonger zal moeten zijn dan vijf-en-twintig jaren, geboren in de Bataafsche Republiek en Meester in de Rechten, mitsgaders rang hebhen....

\section{Art. 85.}

Deze advocaten-adviseurs zullen worden aangesteld door het Staatsbewind uit nominatiën van drie persoonen, door het Nationaal Gerechtshof te formeeren; in cas van vacature geschiedt de provisioneele vervulling door den Gouverneur-Generaal in Rade, uit gelijke nominatiën, door het Hoge Gerechtshof in Bataafsch Indiën geformeerd....

Artt. 87 tot en met 94 .

$$
\text { Art. } 97 \text { (slot) wordt }
$$

Vervallen ${ }^{1}$ ).

....; deselve producten kunnen echter, ingevalle van dringende noodzakelijkheid, ook op andere wijzen tot gelde worden gemaakt voor rekening van den Staat.
Art. 84.

..... door eenen advocaatadviseur, welke niet jonger zal moeten zijn dan vijf-en-twintig jaaren, geboren in de Bataafsche Republiek, of van Europeesche ouders op eene haarer Bezittingen, mits in dit laatste geval zich ten minsten vijf achtereenvolgende jaaren op eene of meerdere 's lands universiteiten in de Rechtskunde hebbende geoeffend; zullende hij voorts moeten zijn Meester in de Rechten, en rang hebben....

Art. 85.

Deze advocaten-adviseurs zullen worden aangesteld door het Staatsbewind. In cas van vacature geschiedt de provisconeele vervulling door den GouverneurGeneraal in Raade, uit nominatiën, door het Hooge Gerechtshof van Bataafsch Indiën geformeerd.

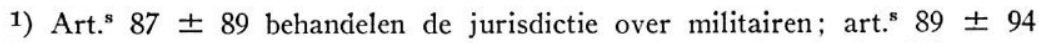
hebben betrekking op het octrooi eener Compagnie tot den theehandel. 
lijk worde gezorgt, dat dezelve ter Bataviasche markt worden gebragt.

Art. 98.

Vervalt.

Art. 99 wordt Art. 90.

.... kruidnagelen, noten-muscaten, koffy, peper en amfioen .... kruidnagelen, noten-muscaten en amfioen.... $\cdots$

$$
\text { Art. } 100 \text { (slot) wordt Art. } 91 \text { (slot). }
$$

....; de vrije en onbelemmerde beschikking daarover komt hem ....; de beschikking daarover komt hem toe, voor zooverre dezelve bij dit Charter, of in byzondere omstandigheden, niet is of wordt beperkt; het is de pligt van het Indische bestuur, hem daarbij te handhaven. Omtrent den handel en uitvoer van koffij en peper nogthans maakt het Staatsbewind zodanige schikkingen, als hetzelve nodig mogt oordeelen, om de uitlevering der contingenten en verpligtte leverantiën te verzekeren, en de smokkelarijen voor te komen.
Art. 105
wordt
Art. 96.

... specerijen, thee, mitsgaders koffij en peper, tenzij omtrent deze twee laatste articulen voldoende kan worden aangetoond, dat dezelve ingehandeld of verkregen zijn in eenige landen of plaatsen, gelegen om de West van Indiën, de Kaap de Goede Hoop daaronder niet begrepen ; $\ldots$ of, bij vervolg, zullen worden bevrijd.

of, bij vervolg, door het Staatsbewind zullen worden bevrijd. 
Art. 108 (slot) wordt Art. 99 (slot).

.... tegen een nader te bepalen $\ldots$. tegen een, door het kost- of vrachtgeld. Staatsbewind nader te bepalen, kost- of vrachtgeld.

Art. 111 wordt Art. 102.

$\ldots$ anders op uitdrukkelijk bekomen permissie.

$\ldots$ anders dan op uitdrukkelijk bekomen permissie.

$$
\text { Art. } 113 \text { wordt Art. } 104 .
$$

..... voorrechten van vrije $\ldots$ voorrechten van vrije vaart en handel op het eiland vaart en handel op het eiland Java, mitsgaders om de West Java, mitsgaders om de West van Indiën ........... mits- van Indiën, alsmede van haven gaders koffij, peper en thee.... tot haven in Oost-Indiën...

.... mitsgaders thee ....

$$
\text { Art. } 116 \text { (slot) wordt Art. } 107 \text { (slot). }
$$

...; alle handel, welke niet uitdrukkelijk door de Wet is verboden, is hun geoorloofd, mits zich onderwerpende aan de plaatselijke ordres en reglementen.

....; alle handel, voor zooverre dezelve niet bij dit Charter of opvolgende wetten wordt bepaald, is hun genorloofd, mits zich onderwerpende aan de plaatselịke ordres en reglementen. 


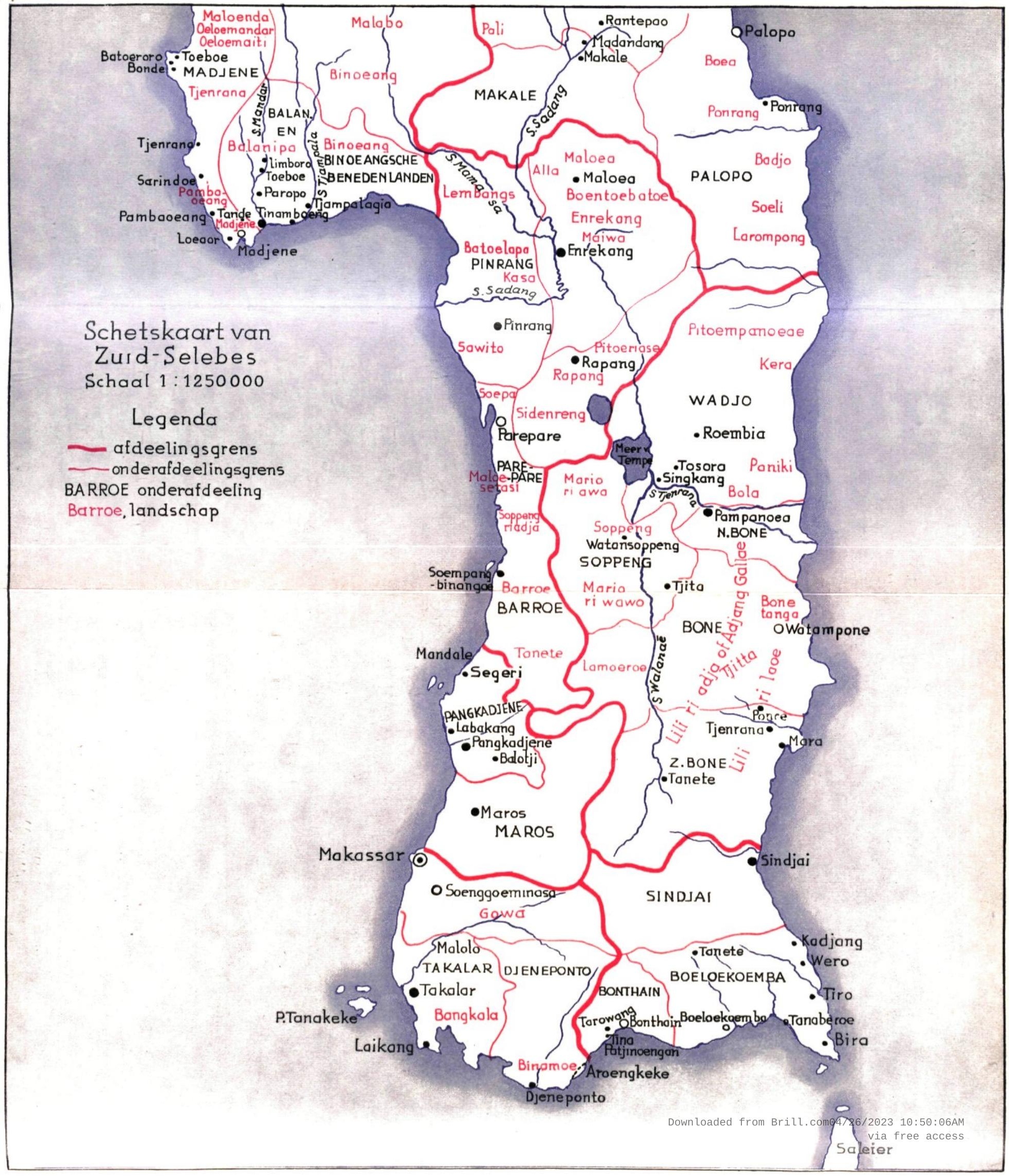

